\title{
Correction: Use of verbal autopsy and social autopsy in humanitarian crises
}

Thomas L-M, D'Ambruoso L, Balabanova D. Use of verbal autopsy and social autopsy in humanitarian crises. BMJ Glob Health 2018;3:e000640. doi: 10.1136/bmjgh-2017-000640.

This article has been corrected since it first published. The author affiliations have been corrected as follows:

Lisa-Marie Thomas (1), Lucia D'Ambruoso (1,2,3), Dina Balabanova (4)

1. Centre for Global Development and Institute of Applied Health Sciences, University of Aberdeen, Aberdeen, UK.

2. MRC/Wits Rural Public Health and Health Transitions Research Unit (Agincourt), School of Public Health, Faculty of Health Sciences, University of the Witwatersrand, Johannesburg, South Africa.

3. Umeå Centre for Global Health Research, Umeå University, Umeå, Sweden.

4. Department of Global Health and Development, London School of Hygiene \& Tropical Medicine (LSHTM), London, UK.

Open access This is an Open Access article distributed in accordance with the terms of the Creative Commons Attribution (CC BY 4.0) license, which permits others to distribute, remix, adapt and build upon this work, for commercial use, provided the original work is properly cited. See: http://creativecommons.org/licenses/by/4.0/

(c) Article author(s) (or their employer(s) unless otherwise stated in the text of the article) 2018. All rights reserved. No commercial use is permitted unless otherwise expressly granted.

BMJ Glob Health 2018;3:e000640corr1. doi:10.1136/bmjgh-2017-000640corr1

Check for updates 